\title{
Public protests spark 'witch-hunt' fears over radiation experiments
}

Washington. Scientists responsible for carrying out radiation experiments on human subjects in the 1960 s should face criminal investigation, a critic of the experiments has told a US congressional committee. And government officials who allegedly concealed some of the experiments could also face the wrath of Congress.

Both the Clinton administration and Congress are seeking to extract maximum political capital from the outcry that has surrounded recent revelations about the experiments. But both are also playing safe by pinning the blame on dead scientists and anonymous officials working under previous administrations.

As public interest grows, however, this approach may prove unsustainable. Many of the individuals involved are still alive, and could face prosecution over their involvement in the research, which was carried out to investigate the effects of radiation on the human body.

Addressing the House of Representatives' energy and power subcommittee last week, David Egilman, a physician from Brown University, Rhode Island, called for the criminal investigation of scientists involved.

Egilman says he plans to take evidence on experiments conducted between 1961 and 1972 at the University of Cincinnati to

the city's prosecutor. He says the research resulted in the deaths of at least eight (and perhaps more than 20) of its 88 subjects, and will ask the prosecutor to indict surviving members of the research team on charges of murder.

At the same subcommittee hearing, Hazel O'Leary, the Secretary of Energy, promised to give Congressman Edward Markey

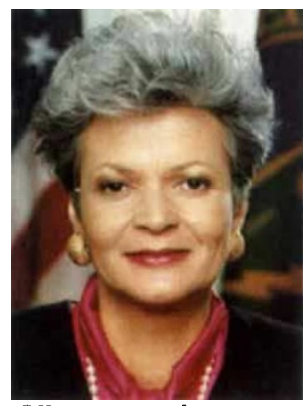

O'Leary: naming names.
(Democrat, Massachusetts) the names of department officials who Markey claims concealed information from him during a 1985 investigation into the issue. O'Leary later denied that this would start a witchhunt within her department: "I'm not after punishment for punishment's sake," she says.

Meanwhile the official inquiry into all radiation experiments conducted in the United States since the Second World War, now being supervised by an advisory committee set up last week by Clinton's executive order, is broadening its scope.

Initially, the Department of Health and Human Services (HHS), which runs most

\section{Nerve gas volunteers demand follow-up study}

London. A group of former servicemen who have taken part in experiments at the Chemical and Biological Defence Establishment at Porton Down since the Second World War is planning to press the government to release detailed information about the nature of the tests in which they were involved.

The servicemen are also planning to push for a long-term follow-up study on volunteers who took part in the tests, including those involving the use of mustard and nerve gas. They want to know whether any of them are suffering from health problems that might have resulted from the tests and, if so, plan to demand compensation from the Ministry of Defence (MoD).

Up to now, the ministry has resisted demands both to open up their records to public scrutiny and to carry out long-term studies of volunteers. Officials have argued that a long-term follow-up study might spread unnecessary alarm among volunteers who remain healthy.

But Mike Roche, a former serviceman who is coordinating the new pressure group, and who took four years to persuade the $\mathrm{MoD}$ to release details to his doctor of the tests he was involved in, says that the recent decision by the US administration to offer compensation to volunteers should now be repeated in Britain.

Roche has written to almost a hundred regional British newspapers asking for individuals involved in the tests to get in touch with him about putting pressure on the government.

He says that he has received many replies from individuals who want to join his campaign (Roche's address is 14 Corporation Road, Rochdale, Lancashire OL114EU).

Others are demanding an inquiry into experiments that took place at St Thomas's Hospital in London in the early 1960s in which patients suffering from terminal cancers were deliberately infected with a form of encephalitis from which several of them subsequently died.

In reply to a parliamentary question earlier this month, Graham Pearson, the current director of Porton Down, revealed that tests involving service volunteers are still being carried out at the research establishment, some involving exposure to the nerve gas, sarin. biomedical research in the United States through the National Institutes of Health (NIH) and other agencies, wanted to be kept out of the inquiry, apart from offering advice to the Energy Department and other agencies under investigation.

But last week it changed tack and started to set up a working group to sift through all relevant research carried out by the department between 1945 and 1975. "We don't know whether there were radiation experiments done by NIH or not," says Avis LaVelle, a spokeswoman for the health department.

The decision by HHS and other departments to be open about radiation testing has been motivated by the the popularity the administration has found on this issue since O'Leary stumbled across it last month. According to a survey in the Wall Street Journal, 63 per cent of Americans consider it "an important issue" compared with 41 per cent for the so-called Whitewater financial scandal dogging the president, and just 29 per cent for allegations about his sex life.

But what is good for the president may be bad for science's public image. Charles Vest, the president of Massachusetts Institute of Technology (MIT), appeared to acknowledge this when, in an unprecedented public apology for MIT's failure to obtain the fully informed consent of subjects for some experiments in the $1950 \mathrm{~s}$, he sought to reassure the public that safeguards have improved since then.

"Medicine has recognized past errors, studied them and really worked to put its house in order," says Dr Mark Siegler, a professor of medicine and director of the Center for Clinical Medical Ethics at the University of Chicago. The conduct of research into human subjects "has evolved to a stage where subjects are given enormous protection," he says.

But Sheldon Krimsky of Tufts University, a former chairman of the scientific freedom and responsibility committee at the American Association for the Advancement of Science (AAAS), fears that public trust in science will be undermined.

Krimsky says the radiation work was "unconscionable" in the face of clear guidelines widely circulated in the wake of Nazi war atrocities. "I'm not sure how deep the mistrust will be, and how to win it back," he says. "But the first thing to do is to set the record straight."

The extent to which rules governing the conduct of research have improved will be the subject of further hearings this week by the Senate Governmental Affairs Committee, chaired by John Glenn (Democrat, Ohio).

Colin Macilwain 